\title{
ON THE EARLY STAGES OF SAMIA COLUMBIA SMITh.
}

BY C. H. FERNALD, ORONO, MAINE.

On the night of the 7th of last June my wife captured at light a fine female Samia colambia. The mo'h was at once secured, her wings p nioned, and she was placed in a cage with the hope that specimens of the other sex might be attracted, but none made their appearance; and on the $n$ ght of the 12th she laid five eggs, glueing them to the gauze on the side of the cage, two in one place and three in another. During the following day (13th) none were laid, but on the night of the 13th she laid fourteen more in several different clusters, and on the night of the 14 th she aid six more. None were laid during the following day and night, and as she was injuring herself with the pinion, she was killed and spread. Whether she wou'd have laid any more had she been kept longer, or whe her she had laid any before her capture, I cannot say.

On the morning of the 26th one of the eggs hatched. I then began to look about for their food plant. Smith states, Proc. Boston Society of Natural History, vol. ix. p. 344, as follows: "They [the cocoons] were mostly attached to Nemopanthes canadensis and Rhodora canadensis; a few were found upon Kalmia angustifolia and maple, and one upon the iarch. The larvæ undoubtedly feed upon the first two plants, and perhaps upon the others; but the cocoons were always where the larvæ might have fed upon the Nemopanthes or Rhodora."

Dr. Packard, in his Synopsis of the Bombycidæ, Proc. Ent. Soc. Phil., vol. iii., p. 380, says: "It (S. columbia) feeds upon Rhodora canadensis, spinning its large cocoons upon the termina! twigs of that shrub."

Guided by these statements, and remembering that Nemopanthes canadensis does not oceur in this region to my knowledge, I first collected Rhodora canadensis, and gave them, but they never so much as tasted it, though I kept a few on it till they were nearly starved. 1) cut the edge of the leaf so they might have easy access to the soft juicy parts of the interior, but all to no purpose. I tried them on Kalmial angustifolia Amelanchier canadensis, maple, beech, white birch, ash, apple, pear, willow, ilex, gooseberry, currant and larch. They just tasted of the last four, but would not feed upon them. I should say that the trial on larch was nor 
satisfactory, as I put one on it and kept it there less than half an hour. Finally I put them on elm, upon which they $f \in d$ a liste, but died one after another.

My friend, Mr. Charles Fish, had been fortunate enough to secure a female which la:d twenty-five eggs, I think, and w:th the young ha'ch d from these he was having a simi'ar experience to my own. He final!y succeeded in getting the remaining few of his to eat wild red herry (Prunus pennsylvanicus). I was ob"ged to leave home at this time, and got my friend, Mr. Anson Al'en, to take the care of my young columb as in my absence. Learning of Mr. Fish's suceess with wild cherry, he pur a part of the remaining number on that plant, leaving a f $\mathrm{w}$ on $\mathrm{e}^{\top} \mathrm{m}$, all of which died, while those fed on the wild cherry succeeded in passing the first moult, and I have been able to carry three through and see them spin up their cocoons successfully. About the time these were in their tater moults Mr. Al'en found two columbia larvæ feeding on larch (Larix americana), so remote from other trees that there could be no possibility of their having crawled on to it from any other tree, and further, these same larvæ continued feeding on the larch in confinement for several days and then spun their cocoons. Mr. Fish also found one or two larve feeding on the larch, several miles from where Mr. Allen's were found. These were all in a very healthy condition, and, it is hoped, wiil yield good imagines next year.

I have observed this s'riking peculiarity in the habits of the larva of columbia, that from the time they hatch till they are done feeding they never wander about, but remain upon a leaf or twig entire'y unsuitable for food till they starve, even though there be fresh food within half an inch of them.

When they are fully grown and are done feeding, they evacuate their bodies and then begin to travel around their enclosure, continuing their travels sometimes for twenty-four hours, till they find a suitable prace ir. which to sp: $n$ their cocoons. At first they spin a certain amount of white or silver-colored silk, and after that has been expended, the brown silk. One of the larvæ wandered about for a long time before it appeared to get ready, or to find a suitable place in which to spin its cocoon, and all this time it was wasting its silvery silk, spinning it freely as it crawled slowly over the surface of the glass forming one side of the breeding cage. At last a satisfactory place was found, and the cocoon spun, but almost entirely without the characteristic silvery bunches upor 
the outs:de, for the simple reason, as it wou d seem, that the larva had no white silk remaining to give the appearance usualy seen upon the outside. I further observed that those which spun up immediately, without wandering about much, make cocoons with the most complete silvery hunches upon them. After the first long threads of the cocoons have been extended, the arva moves its mouth back and for h for a considerable length of time in one place, as far as it can move its head, thus dopositing a large amount of the slvery silk in this place; then moving to another pace. he same operation is performed, and so on over the whole exposed parts of the cocoon. I did not see that they deposited any of the silk in this way against the under surface of the glass when the cozoon was paced against ił. Nearly all of the cocoons which have been found here were on the larch, and these silvery bunches certainly give them a very close resemblance to the bark of that tree.

Egg-Sub-globose, sightly ccmpressed, the compression being least upon the side from which the young escapes; cream-colored, clouded with reddish-brown, and a tached to the object upon which the female deposits by means of a dark brown adhesive substance, which appears to be the same as that which is clouded over the surface of the egg, but the greater abundance of it at the point of attachment produces a much darker color. Greatest diameter, 2 mil.; medium, $14 / 5$ mil.; least diameter, $12 / 5 \mathrm{mil}$. The eggs hatched in fourteen and fifteen days after they were deposiced.

Young Larva-Length immediately after escaping from the egg shell, 4 mil. Color black; some of the ind viduals show a greenish tinge around the base of the tubercles. Body eylindrical, slightly tapering towards the posterior extremity; head large, rounded, sparsely e othed with long hairs. The second (first after the head), third, fourth, fifth, and sixth segmen's each with eight tubercles, the lowest one on each side much smaller than the others. The seventh, eighth, ninth, tenth and e'eventh segments have each six tubercles, rather smaller than the corresponding ones on the preceding segments. The twelfth segment has five tubercles, two on each side corresponding with those on the preceding segment in size, and one on the middle of the dorsum of the same size as the upper ones on the third segment. The thirteenth segment has four tubercles on the anterior edge and one at the base of each anal proleg. The tuberc'es are smooth, cylindrical, gradually enlarging towards the base and at the summit, the least dameter being about two-thirds the way up; length equal to about three times the least diameter, surmounted with 
from two (on the smallest) to six finely serrated, radiating bristles which are about twice the length of the tubercles. Duration of this stage eight to nine days.

After the First Moult-Length (taken a short time before the second moult), 15 mil. Color pea green. Tubercles and bristles, mandibles, pa pi and antennæ, a spot about the eyes, a stripe on each side of the clypeus, the legs and a spot on the outside of the prolegs, black. Second, third and fourth segments each with four black spots on the posterior edge and a row of black spots on each segment after the head, on the line of and behind the sigmatx. Duration of this stage five to seven days.

After the Second Moult-Length (taken soon after the second moult) 20 mil. Color pea green with a bluish tint upon the dorsum. Black markings as in preceding stage. Duration of this s'age four to five days.

After the Third Moult-Length $35 \mathrm{mil}$. Color pea green, lighter on the dorsum. Marked with black as in the two preceding stages. All the tubercles with the basal portions blue, except those on the second segment and the lower one on each side of the third to the sixth segments inclusive. Duration of this stage six to nine days.

After the Fourth Moult-Length 50 mil. The head at the time the larva escaped from the egg-shell was proportionally large, but during the s.c eeding siages it did not griw so fast as the other parts of the larva, and at the beginning of this siage, but more especialy at its close, it was proportionally small. Duration of this stage ten to twelve days.

Mature Larva-Length 76 mil. - about three inches. Thickness between the segmen.s 13 mil., of largest part of segment 15 mil.

Head pea green, sparsely clothed with fine yellowish hairs. Mandibles, outer joints of antennæ and palpi, spot about the eyes, two spots on ine gular (these may have occurred in the previous stages, but were not observed), and a stripe on each side of the clypeus, black, the latter sometimes wanting. Basal joints of antennæ and palpi and the labrum greenish biue. General color of the body pea green, rather lighter than the head, and ighter above than on the sides, with the faintest tinge of blue between the segments. Last joint of the legs and claw black. Stigmatæ oval, white, surrounded by a fine black line.

The tubercles were greatly changed at the fourth moult, both in form and color. The first and lowest on the second segment is small, conical, black and surmounted by a few short, stout, black spines. The second is 
more rounded at the top, shining black at the base, and resembing white giazed porcelain a the apex, with four black spines. The next two are smaller, about 21/2 mil. apart on the front edge of the segment, the 1 wer of which is about 5 mil. from No. 2. These are very small and black, the upper one having a trace of greenish-white at the apex, and both are surmounted with several short black spines. The lowest tubercles on segments three to six inc usive are small with black bases, apices resembling white glazed porceiain, and generally two black spines. The $t$ bercles of the next row above, extending from the third to the las $t$ segments inclusive, are very similar in form and color, but larger; those of the row acove this are slightly pear-shaped, a very little thickened towards the outer end, of the same co'or as the preceding, and surmounted with from four to six short stou black spines. Those of the next row on the third, fourth and fifth segments, and the corresponding ones on the opposite $s$ de of the dorsum-by far the largest on the larva-are pear-shaped, largest outwardly, porcelain white at the base, with a band of shining black above, and a bright coral-red top, with from six to eight stout black spines. The tubercles of this row on the sixth to the eleventh segments inclusive are nearly as tall, but slimmer than those preceding, sightly curving backwards, porce ain white at the base, a very light straw color above and armed wi h two black spines at the top. The dorsal tubercle of th? twelfth segment is very similar, but larger, and armed wi'h several biack spines. The tuberc'e at the base of the anal proleg is smaller than those before it, of a light b.uish color, with black at the base outside.

The most striking differences observed between $P$. columbia and $P$.

cecropia, in a brood of the latter raised by the side of the former, arefirst, the smaller size of columbia at each of the stages; the mature larva of columbia is about three inches in length, that of cecropia about four. Second.y, columbia is of a clear light pea green co or, cecropia a dull bluish green, giving a much darker aspect to this larva. This distinction of color is so mariced that if once observed, the one can never be mistaken for the other. Thirdly, columbia has three pairs of coral-red tubercles, one pair each on the third, fourth and fifth segments; cecropia has two pairs, one pair each on the third and fourth segments. Then the color of these differ; those of columbia are a true coral or vermilion-red, while all the cecropias I have seen have these tubercles a color somewhat approximating that of resin. The remaining dorsal pairs of tubercles to the twelfth segment, and the central one on the twelfth, are lemon yellow, while in 
columbia they are white at base and a very light straw color above. The remaining tubercles of cecropia are black at the base and bie above; in columbia they axe biack at the base, but with the look of white gazed porcelain above. These distinctive characters showed no tendency to run into each other in any of the examples I have seen. As perhaps having a bearing upon the question whether columbia is a hybrid between cecropia and promethea, I will say that in six years of careful collecting at this place I have never taken a promethea, nor has one ever been taken here to my knowedge; yet the empty cocoons of columbia have occasionally been found, mostly in larch trees, in one instance about forty feet from the ground.

I am therefore convinced that columbia is a good species, but whether distinct from Gloveri I am not prepared to express an opinion.

In my observations on columbia I have been greatly assisted by Messrs. Allen and Fish, who rendered every possible aid and piaced their noies at my entire disposal.

\section{ON FOOD PLANTS OF PAPILIO CRESPHONTES (THOAS).}

\section{BY THE EDITOR.}

In September last we were much gratified, although somewhat surprised, at receiving a number of the larvæ of this beautif $\mathbf{u}_{-}$butterfly from Mr. S. Eccles, of St. Thomas, Ontario, a town situated about 17 miles south of London, and about half way between it and Lake Erie. They were found in Mr. Eccles' garden, feeding on Dictamnus fraxinella, a perennial herb which is a native of Southern Europe, but cultivated in this country for ornament in gardens. The larvæ were in different stages of growth, from one to two inches in length, and were feeding greedily on the plan $乞$ referred to. We had never seen this larva before, but its markings are so peculiar that we recognized it at once from recollection of the figure given in Boisduval \& LeConte, pl. 13. As this description may not 